Шпура М. І., к.військ.н., с.н.с.;

Федянович Д. Л., к.військ.н., с.н.с.;

Андріянова Н. М.

Центр воєнно-стратегічних досліджень Національного університету оборони України імені Івана Черняховського, Київ

\title{
Аналіз підтримки, що надає НАТО силам безпеки і оборони інших країн на прикладі Афганістану
}

Резюме. У статті проведено аналіз надання підтримки силам безпеки Афганістану з боку НАТО. Визначено основні ключові напрями діяльності Північноатлантичного Альянсу в ході “Операції 3 підтримання безпеки в Афганістані" силами контингенту ISAF, місії "Рішуча підтримка" та довгострокового співробітництва.

Ключові слова: воєнна безпека; місія НАТО “Рішуча підтримка"; підтримка сил безпеки і оборони; національні сили безпеки Афганістану; національні збройні сили; НАТО.

Постановка проблеми. На сьогодні колективна оборона залишається головним завданням НАТО. Поява нових викликів i загроз, які виникають далеко за межами зони відповідальності цієї Організації, зокрема тероризм, становлять собою виклики, які неможливо подолати, виходячи лише 3 “територіального" розуміння безпеки.

Підтвердженням тому $є$ діяльність Альянсу щодо надання підтримки іншим країнам, основною метою якої є допомога у розбудові ефективних інститутів оборони і безпеки [1].

У грудні 1991 року у НАТО було створено раду північноатлантичного співробітництва, яку у 1997 році було перейменовано у Раду євроатлантичного партнерства. У рамках цього форуму НАТО мала можливість проводити консультації 3 іншими країнами у Центральній та Східній Європі. Поступово це співробітництво було розширене на південь. У 1994 році Альянс розпочав Середземноморський діалог 3 країнами, що не були його членами (Сгипет, Ізраїль, Йорданія, Марокко i Туніс). 3 2003 року НАТО спрямувало свою діяльність на підтримку міжнародних зусиль по зміцненню безпеки і стабільності у Ісламській Республіці Афганістан.

Отже, вивчення i аналіз підтримки НАТО сил безпеки інших країн $є$ важливим 3 огляду на процеси, що відбуваються на сході України.

Інформаційною базою для написання статті $\epsilon$ матеріали Міністерства оборони України, документація НАТО 3 питань продовження сприяння місії "Рішуча підтримка" та довгострокового співробітництва між НАТО та Афганістаном.

Мета статті. Проаналізувати досвід діяльності НАТО щодо надання підтримки інститутам оборони і безпеки Афганістану під час "Операції 3 підтримання безпеки в Афганістані" силами контингенту ISAF (International Security Assistance Force) під час місії НАТО "Рішуча підтримка" (РП-А), а також у рамках довгострокового співробітництва.

Виклад основного матеріалу. За результатами Боннської конференції, яка відбулася восени 2001 року та згідно 3 резолюцією Ради Безпеки ООН № 1386 (2001) від 20 грудня 2001 року ініційованою Великою Британією, у грудні 2001 року були створені Міжнародні сили сприяння безпеці (МССБ) в Ісламській Республіці Афганістан.

Підтримка під час "Операції 3 підтримання безпеки в Афганістані” силами контингенту ISAF. Мандат МССБ спочатку обмежувався забезпеченням безпеки в Кабулі та навколо нього. У жовтні 2003 року ООН поширила повноваження МССБ на усю територію Афганістану (Резолюція РБ ООН № 1510), що поклало шлях для розширення діяльності місії по всій країні у чотири етапи.

Перший етап. У грудні 2003 року Північноатлантична рада уповноважила Верховного головнокомандувача об'єднаних збройних сил генерала Джеймса Джонса розпочати розширення МССБ, переймаючи командування над групою реконструкції провінції (ГРП) у Кундузі. Інші вісім ГРП, що виконували завдання в Афганістані у 2003 році, залишались під командуванням військової операціï "Enduring Freedom" під проводом США. 
Характеристика підтримки сил безпеки і оборони Афганістану

\begin{tabular}{|c|c|c|}
\hline $\begin{array}{c}\text { Характеристики } \\
\text { підтримки сил } \\
\text { безпеки } \\
\end{array}$ & $\begin{array}{c}\text { Підтримка в рамках Операції } 3 \\
\text { підтримання безпеки силами } \\
\text { контингенту ISAF } \\
\end{array}$ & $\begin{array}{c}\text { Підтримка в рамках } \\
\text { місії НАТО - "Рішуча підтримка" }\end{array}$ \\
\hline $\begin{array}{l}\text { Підстави для } \\
\text { розгортання місії } \\
\text { (операції) }\end{array}$ &  & $\begin{array}{l}\text { Резолюція Ради Безпеки ООН № } 2189 . \\
2 \text { грудня 2014 року на засідання } \\
\text { Північноатлантичної ради на рівні міністрів } \\
\text { закордонних справ у форматі потенційних } \\
\text { операційних партнерів РП-А офіційно } \\
\text { затверджено Виконавчу директиву щодо } \\
\text { початку виконання органами військової } \\
\text { командної структури нАТО Операційного } \\
\text { плану РП-А та анонсовано започаткування } \\
\text { діяльності нової місії Альянсу }\end{array}$ \\
\hline $\begin{array}{l}\text { Наз上 } \\
\text { (опе }\end{array}$ & \begin{tabular}{l}
\multicolumn{1}{l}{ Операція } \\
Афгідтримання безпеки в \\
Афгастані \\
(International \\
ISAF)
\end{tabular} & $\begin{array}{l}\text { Місія НАТО “Рішуча підтримка" (РП-А). } \\
\text { Місія по учбовій підготовці консультуванню та } \\
\text { сприянню афганським силам безпеки [3] }\end{array}$ \\
\hline $\begin{array}{l}\text { Ман } \\
\text { (опе }\end{array}$ & 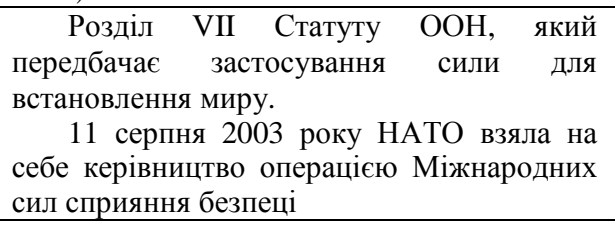 & $\begin{array}{l}27 \text { листопада } 2014 \text { року афганська сторона } \\
\text { офіційно заявила про завершення процедури } \\
\text { ратифікації Угоди між HATO та Афганістаном про } \\
\text { статус збройних сил NATO SOFA) та набуття нею } \\
\text { чинності з } 01 \text { січня } 2015 \text { року }\end{array}$ \\
\hline $\begin{array}{l}\text { іяні в } \\
\text { i) }\end{array}$ & $\begin{array}{cccc}\text { Міжнародні сили сприяння безпеці в } \\
\text { Ісламській Республіці Афганістан (МССБ). } \\
\text { Станом на } 1 \text { червня } 2014 \text { року } \\
\text { чисельність МССБ } \text { складала } \\
49 \text { тис. } 902 \text { військових з } 48 \text { країн }\end{array}$ & \begin{tabular}{l}
\multicolumn{1}{l}{ Загальна чисельність місії становить за } \\
штатом - 15258 осіб (за списком - 13420 осіб, \\
12905 осіб у 2015 році) 39 країн-контрибуторів, 3 \\
яких 27 країн-членів НАТО та 12 країн-партнерів \\
(Австралія, Австрія, Азербайджан, Боснія і \\
Герцеговина, Вірменія, Грузія, Македонія, \\
Монголія, Нова Зеландія, Україна, Швеція та \\
Фінляндія)
\end{tabular} \\
\hline $\begin{array}{l}\text { Метс } \\
\text { (опе) }\end{array}$ & $\begin{array}{l}\text { Надання можливості перехідному уряду і } \\
\text { Місії ООН з допомоги Афганістану діяти в } \\
\text { столиці м. Кабул в умовах безпеки, а також } \\
\text { встановлення та підтримання безпечного і } \\
\text { стабільного середовища, сприяння } \\
\text { діяльності законно обраного центрального } \\
\text { уряду та місцевих органів самоврядування. } \\
\text { Створення безпечного середовища для } \\
\text { роботи Місії ООН [1] }\end{array}$ & \begin{tabular}{l}
\multicolumn{1}{c}{ Надання уряду Афганістану подальшої } \\
допомоги у розвитку Афганських національних \\
сил безпеки і оборони (АНСБО) після сприяння \\
безпеці в Ісламській Республіці Афганістан \\
(МССБ). \\
Надання дорадчо-консультативної допомоги \\
уряду Афганістану щодо розвитку операційних \\
спроможностей АНСБО, у т.ч. із застосуванням \\
експедиційних груп радників (Expeditionary \\
Advisory Package) поза межами пунктів постійної \\
дислокації [2-4]
\end{tabular} \\
\hline $\begin{array}{l}\text { Особ } \\
\text { діяль }\end{array}$ & $\begin{array}{l}\text { Міжнародні сили } 3 \text { самого початку } \\
\text { створювалися не як сили ООН, а як } \\
\text { коаліційні сили, розгорнуті в Афганістані } \\
\text { згідно з рішенням Ради Безпеки ООН }\end{array}$ & $\begin{array}{l}\text { Розглядається НАТО як небойова місія, що } \\
\text { виконується для підтримки подальшого розвитку } \\
\text { національних сил безпеки і оборони }\end{array}$ \\
\hline $\begin{array}{l}\text { Осног } \\
\text { місіі }\end{array}$ & $\begin{array}{l}\text { Визначені Військово-технічною угодою } \\
\text { між командувачем МССБ та перехідним } \\
\text { урядом Афганістану у січні } 2002 \text { року: } \\
\text { - захист цивільного населення країни та } \\
\text { відновлення законності; } \\
\text { - сприяння та підвищення ефективності } \\
\text { діяльності національних урядових } \\
\text { структур; } \\
\text { - боротьба із незаконними збройними } \\
\text { формуваннями та тероризмом; } \\
\text { - відновлення інфраструктури країни; } \\
\text { - надання допомоги у розбудові } \\
\text { національних сил безпеки та поступова } \\
\text { передача їм повноважень з підтримання } \\
\text { безпеки в країні; } \\
\text { - сприяння у проведенні реформ та } \\
\text { протидія незаконному обігу наркотиків }\end{array}$ & $\begin{array}{l}\text { Підготовка та надання консультативно- } \\
\text { дорадчої допомоги безпековим інституціям та } \\
\text { установам країни, а також керівній ланці армії та } \\
\text { поліції. } \\
\text { Розвиток спроможностей АНСБО у таких } \\
\text { ключових сферах як: } \\
\text { - стратегічне планування; } \\
\text { - формування та управління силами і } \\
\text { засобами; } \\
\text { - ресурсне забезпечення; } \\
\text { - ведення розвідки та спостереження; } \\
\text { - повітряне перевезення та повітряна } \\
\text { підтримка наземних операцій; } \\
\text { - бюджетне планування, фінансовий контроль } \\
\text { та інформаційне забезпечення. } \\
\text { Окрім цього, члени коаліції продовжують } \\
\text { надавати уряду Афганістану фінансову } \\
\text { допомогу для забезпечення діяльності АНСБО } \\
\text { [2-4] }\end{array}$ \\
\hline
\end{tabular}

28 червня 2004 року під час зустрічі на вищому рівні керівництва держав та урядів країн НАТО в Стамбулі [2], оголосили про початок діяльності ГРП на півночі 
Афганістану. Цей процес був завершений 1 жовтня 2004 року, що визначило завершення першого етапу розширення МССБ.

Другий етап. 10 лютого 2005 року НАТО було оголошено про початок розширення МССБ на захід країни. Цей процес розпочався 31 травня 2006 року, коли МССБ очолила дві додаткові ГРП у провінціях Герат і Фарах.

На початку вересня на заході Афганістану почали функціонувати ще дві ГРП під керівництвом МССБ, у провінціях Чагчаран та Багдаді, що завершило розширення МССБ на західному напрямку.

Після розширення діяльності, МССБ очолювала діяльність дев'яти ГРП на півночі та заході, охоплюючи близько $50 \%$ території Афганістану. Альянс продовжував проводити підготовку до подальшого розширення на афганському півдні.

У вересні 2005 року Альянс також тимчасово направив 2 тис. осіб військового персоналу для підтримки проведення провінційних та парламентських виборів.

Третій етап. 8 грудня 2005 року в штабквартирі НАТО в Брюсселі міністри закордонних справ країн-членів Альянсу схвалили план, який проклав шлях для розширення ролі та присутності МССБ в Афганістані. Першим елементом цього плану було розширення МССБ на південь у 2006 році. Це було здійснено 31 липня 2006 року, коли МССБ узяли на себе командування південним регіоном Афганістану від коаліційних сил під керівництвом США, розширивши зону відповідальності ще на 6 провінцій та очоливши діяльність чотирма додатковими ГРП.

Загалом, МССБ очолило діяльність 13 ГРП на півночі, заході та півдні, що охоплювало близько трьох чвертей території Афганістану. Чисельність сил МССБ в країні також істотно зросла, приблизно 310000 до розширення та близько 20000 після.

Четвертий етап. 5 жовтня 2006 року МССБ здійснили заключний етап свого розширення, взявши на себе командування міжнародними військовими формуваннями у східній частині Афганістану від коаліційних сил під проводом США.

Загалом, 32006 до 2011 року, МССБ були залучені в інтенсивні бойові дії 3 угрупованнями бойовиків ісламістських рухів опору, зокрема у південних та східних провінціях Афганістану.

У результаті проведення операції НАТО, і особливо США, зазнали суттєвих фінансових втрат та втрат у особовому складі і військовій техніці. Підсумовуючи результати
2013 року Генеральний секретар НАТО зауважив, що МССБ поступово переходять від завдання із забезпечення безпеки Афганістану до завдання підтримки АНСБО [5]. На початку 2013 року присутність МССБ складала 105 тис. військовослужбовців, а кількість баз та об'єктів досягала 184. До кінця 2013 року у складі угруповання залишилося 75 тис. військовослужбовців та 88 баз і об'єктів. Дії МССБ були спрямовані на забезпечення власної безпеки. Основні функції забезпечення безпеки в країни почали виконувати національні сили безпеки і оборони (352 тис. осіб). За даними [5] під час першого сезону бойових дій, коли основні функції виконували вже афганці ними було проведено $95 \%$ операцій 3 використання звичайних сил та засобів і 98 \% спеціальних операцій.

Остаточно діяльність МССБ із забезпечення безпеки Афганістану було закінчено 31 січня 2015 року у зв'язку 3 початком нової місії НАТO - "Рішуча підтримка" (Resolute Support Mission (RSM)) [3].

Підтримка в ході виконання місї “Рішуча підтримка” (РП-А). Принциповою функцією місії РП-А $\epsilon$ надання дорадчоконсультативної допомоги уряду Афганістану щодо розвитку операційних спроможностей АНСБО, у т.ч. із застосуванням експедиційних груп радників (Expeditionary Advisory Package) поза межами пунктів постійної дислокації. За словами Генерального секретаря НАТО місія РП-А $є$ місією по учбовій підготовці консультуванню та сприянню афганським силам безпеки, загальне політичне керівництво діяльності якою здійснюється Північноатлантичною радою. Безпосереднє керівництво покладене на командувача місією та штаб (м. Кабул). Розташування підрозділів місії РП-А наведено на рис. 1.

Напередодні зустрічі лідерів НАТО у Брюсселі 25 травня 2017 року з метою забезпечення довгострокової безпеки i стабільності в Афганістані, країни-члени Альянсу підтвердили свої зобов'язання щодо забезпечення подальшої діяльності Miciї, прийняті під час проведення Варшавського саміту НАТО (08-09.07.2016). Було зазначено, що Афганські національні сили безпеки покращили свій рівень, але все ще потребують підтримки. Партнери по Місії погодились продовжувати надання консультативнодорадчої допомоги та проведення підготовки афганських органів і сил безпеки [4].

Ураховуючи тенденції розвитку безпекової та політичної ситуації в Афганістані, а також збереження залежності АНСБО від всебічної міжнародної допомоги, на Саміті НАTO у Варшаві були затверджені спільні рекомендації 




Рис. 1. Розташування структурних підрозділів місії НАТО в Афганістані “Рішуча підтримка" $[2,3]$

- відмова від згортання регіональних тренувально-дорадчих командувань та недопущення зниження рівня військової присутності НАТО в Афганістані;

- надання уряду Афганістану подальшої фінансової допомоги для забезпечення діяльності та розвитку спроможностей АНСБО у період 2018 - 2020 рp.;

- продовження реалізації заходів щодо поглиблення Стійкого партнерства 3 Афганістаном (Enduring Partnership).

У цьому контексті є чітке розуміння, що перехід від місії РП-А до обмеженої цивільновійськової присутності у рамках поглибленого партнерства 3 Афганістаном має відбутися виключно після досягнення необхідних передумов, які виключатимуть втрату здобутків Альянсу в цій країні.

У рамках практичної реалізації рішень, прийнятих на Варшавському саміті НАТО, а також 3 метою підвищення ефективності подальшої діяльності місії РП в Афганістані, запроваджено низку змін у контексті взаємодії $з$ АНСБО, зокрема:

- розширені повноваження місії щодо надання консультативно-дорадчої допомоги АНСБО. Це передбачає збільшення загальної чисельності міжнародних радників для забезпечення можливостей місії РП з надання тренувально-дорадчої допомоги не лише на рівні штабів армійських корпусів АНА та регіональних управлінь АНП, але і на рівні підрозділів (до батальйону включно) поза межами визначених коаліційних баз або навчальних установ. Особлива увага приділяється питанням підвищення професіоналізму військових керівників стратегічної та оперативної ланок управління, а також нарощенню спроможностей Афганських повітряних сил;

- місія надає підтримку АНСБО при проведенні операцій (у т.ч. щодо безпосередньої авіаційної підтримки, повітряного перевезення та медичної евакуації, ведення розвідки та спостереження тощо);

- запроваджено більш гнучкий підхід до планування наступної фази діяльності місії РП-А, перехід до якої має бути здійснено лише 3 урахуванням досягнення необхідних умов та розвитку ситуації в країні (conditions-based approach);

- активізовано процеси в рамках розвитку Стійкого партнерства 3 Афганістаном (Enduring Partnership) [2].

Відповідальність за загальну координацію заходів 3 посилення Стійкого партнерства 3 Афганістаном покладено на Об'єднану групу оперативного планування (Integrated Core Planning Team), створену в штаб-квартирі НАТО. Групу очолює представник Департаменту операцій Міжнародного секретаріату Альянсу. До ii складу входять спеціалісти Міжнародного секретаріату та Міжнародного штабу НАТО, представники обох стратегічних командувань Альянсу, а також Офісу Старшого цивільного представника НАТО в Афганістані. 
Загальний контроль за діяльністю Групи забезпечується заступником помічника Генерального секретаря НАТО з операцій.

У своїй діяльності Група планування підтримує тісну взаємодію 3 Відділом координації стійкого партнерства штабу місії РП (Enduring Partnership Coordination Cell, RS HQs).

Основні завдання відділу координації:

забезпечення взаємодії 3 афганською стороною, насамперед, щодо визначення вимог i напрямів підготовки афганських фахівців;

контроль процесу відбору кандидатів для участі у програмах фахової та спеціалізованої підготовки, a також їх подальшого застосування в інтересах АНСБО; надання допомоги АНСБО у створенні подібної системи контролю та координації заходів підготовки; підтримання представництвами інших держав та міжнародних організацій, які реалізовують двосторонні проекти 3 підготовки афганських спеціалістів, з метою уникнення дублювання зусиль та в рамках забезпечення загальної координації дій;

надання можливої адміністративної i технічної допомоги при проведені навчальних заходів в Афганістані тощо.

Ключовим органом, відповідальним за підтримання взаємодії з Відділом координації штабу місії РП, визначений Секретаріат Ради Національної Безпеки Афганістану.

На засіданні 9 листопада 2017 року міністрами оборони всіх 39 країн-учасниць, було розглянуто 4 ключові питання: рівень військової присутності Місії, фінансування Афганських сил безпеки, прогрес у здійсненні реформ та процесі примирення, а також продовження взаємодії з Пакистаном.

У контексті реалізації нової стратегії Сполучені Штати Америки заявили про збільшення кількості своїх військ у Місії. 27 інших країн також взяли на себе зобов' язання збільшити кількість свої військ у найближчі місяці. Генеральний секретар НАТО заявив, що військовий компонент Мiciї буде збільшено 313 до 16 тис. військовослужбовців.

Наразі триває уточнення перспективних планів діяльності, структури місії та забезпечення укомплектованості іiі структурних підрозділів.

Країни НАТО та партнери значно збільшили щорічні внески у фінансування сил безпеки Афганістану. У Варшаві на зустрічі високого рівня було прийнято рішення щодо продовження фінансової підтримки до 2020 року Міжнародна спільнота підтримує
Афганістан у рамках двох фондів - цільовий фонд $\mathrm{OOH}$ на підтримку правопорядку i Цільовий фонд Афганської національної армії, яким керує НАТО. За даними [4] загальний щорічний обсяг внесків у ці фонди склав близько 1 млрд доларів США. До кінця 2024 року планується, що Афганістан буде спроможний самостійно виконувати зобов'язання по фінансуванню власних сил безпеки i оборони (на сьогодні цей обсяг складає близько 500 млн доларів США). Водночас США будуть продовжувати фінансову допомогу і після 2024 року, але вже на двосторонній основі.

Підтримка в рамках довгострокового cniвробітництва. Незважаючи на те, що НАТО зосереджує зусилля 3 підтримки Афганістану в рамках місії РП-А та фінансування афганських сил безпеки, продовжується робота i в галузі довгострокового партнерства, яке включає політичний діалог та практичне співробітництво між НАТО та Афганістаном [2-4].

Довгострокове партнерство включає ряд узгоджених програм та заходів по співробітництву, які допомагають зміцнити потенціал не тільки сил безпеки і оборони, а й економічний потенціал країни у цілому. Важливими програмами допомоги є Програма НАТО по зміцненню етичних основ та Програма поглиблення військової освіти. Ці програми $\epsilon$ суттєвими у підвищенні транспарентності і підзвітності, зниження ризику корупції у секторі безпеки і оборони.

Серед інших галузей практичного співробітництва можна відмітити цивільне надзвичайне планування i готовність до реагування на стихійні лиха та катастрофи, залучення жінок до служби у збройних силах.

\section{Висновки:}

1. Підтримка сил безпеки i оборони Афганістану проводиться НАТО за трьома важливими напрямами - у рамках небойової місії "Рішуча підтримка", яка стала логічним продовженням бойової операції - "Операції 3 підтримання безпеки в Афганістані” силами контингенту ISAF, фінансова підтримка в рамках фонду, яким керує НАТО спільно 3 фондом ООН та в рамках довгострокового співробітництва.

2. Незважаючи на значний обсяг фінансування та підтримки сил безпеки i оборони Афганістану не спроможні повністю контролювати ситуацію в країні самостійно без міжнародної допомоги.

3. Перспективним напрямом практичної допомоги НАТО Афганістану вважається 
поступовий перехід до Стійкого партнерства.

Подальші дослідження доцільно зосередити на вивченні досвіду підтримки Альянсом сектору безпеки і оборони інших країн, що не $є$ членами НАТО, зокрема України, з метою визначення концептуальних підходів, загальних принципів і тенденцій щодо надання допомоги, а також особливостей формування і прийняття рішень на підтримку окремих країн у політичній, воєнній та інших сферах.

\section{СПИСОК ВИКОРИСТАНОЇ ЛІТЕРАТУРИ}

1. NATO, Istanbul Summit. [Електронний ресурс]: Режим доступу: http://www.nato.int/docu/ comm/2004/06-istanbul/home.htm.

2. Річний звіт Генерального секретаря НАТО 2015. [Електронний ресурс]: - Режим доступу: www.nato.int.

3. Річний звіт Генерального секретаря НАТО 2014. [Електронний ресурс]: - Режим доступу: www.nato.int.

4. Річний звіт Генерального секретаря НАТО 2016. [Електронний ресурс]: - Режим доступу: www.nato.int.

5. Річний звіт Генерального секретаря НАТО 2013. [Електронний ресурс]: - Режим доступу: www.nato.int.

Стаття надійшла до редакції 06.03.2018

Шпура Н. И., к.воен.н., с.н.с.;

Федянович Д. Л., к.воен.н., с.н.с.;

Андриянова Н. Н.

Центр военно-стратегических исследований Национального университета обороны Украины имени Ивана Черняховского, Киев

Анализ поддержки, которую оказывает НАТО силам безопасности и обороны других стран на примере Афганистана

Резюме. В статье проведен анализ поддержки, которую оказывает НАТО силам безопасности и обороны Афганистана. Определены основные ключевые направления деятельности НАТО в ходе "Операции по поддержанию безопасности в Афганистане" силами контингента ISAF, миссии “Решительная поддержка” и долгосрочного сотрудничества.

Ключевые слова: военная безопасность; миссия НАТО “Решительная поддержка”; поддержка сил безопасности и обороны; национальные силы безопасности Афганистана; НАТО.

\section{Fedyanovich PhD (Military), senior researcher;}

\section{Shpura PhD (Military), senior researcher;}

\section{N. Andriianova}

Center for Military and Strategic Studies of the National Defence University of Ukraine named after Ivan Cherniakhovskyi, Kyiv

Analysis of the support provided by NATO to the security and defense forces of other countries on the example of Afghanistan

Resume. This article examines military and political aspects of NATO participation in operations abroad. The chronology of NATO's participation in international operations is defined and the practical aspect of participation is presented, including the already completed missions and the ongoing ones.

Keywords: peacekeeping operations; military policy; security; armed forces; UN; NATO; EU. 